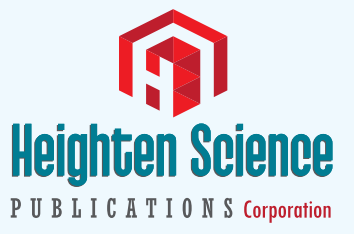

ISSN

2573-7724

\title{
Radiological assessment of exposure doses and radon exhalation rates of building materials in Saudi Arabia
}

\author{
Mohsen B Challan ${ }^{1,2 *}$ and Atteyat A Labib ${ }^{2,3 * *}$ \\ 'Department of Physics, College of Science in Zulfi, Majmaah University, Majmaah 11952, \\ Saudi Arabia \\ ${ }^{2}$ Departmant of Experimental Nuclear Physics, Nuclear Research Center, Atomic Energy \\ Authority of Egypt, Cairo 13759, Egypt \\ ${ }^{3}$ Department of Food Science \& Human Nutrition, College of Agriculture \& Veterinary Medicine, \\ Qassim University, Buraydah 52383, Saudi Arabia
}

\begin{abstract}
*Address for Correspondence: Mohsen B Challan, Department of Physics, College of Science in Zulfi, Majmaah University, Majmaah 11952, Saudi Arabia, Tel: +966-54-368-0294; Fax: +966-16-422-5721; Email: m.shaalan@mu.edu.sa

Atteyat A. Labib, Department of Food Science and Human Nutrition, College of Agriculture and Veterinary Medicine, Qassim University, Buraydah 52383, Saudi Arabia, Tel: +966-55-8065846; Fax: +966-16-385-7079; Email: mhmodaa@qu.edu.sa
\end{abstract}

Submitted: 20 February 2018

Approved: 22 February 2018

Published: 23 February 2018

Copyright: @ 2018 Challan MB. This is an open access article distributed under the Creative Commons Attribution License, which permits unrestricted use, distribution, and reproduction in any medium, provided the original work is properly cited.

Keywords: Radium; Radon exhalation rates; Exposure dose; Effective doses; SSNTD CR-39

\section{Abstract}

In the present work, samples of building material are analyzed for their naturally occurring radioisotope activity such as uranium, radium, and radon. The radon emission rates, and the annual effective doses, "AED", are also investigated. The activity of twenty-four samples, taken from the local markets of Saudi Arabia, was determined using the "Sealed-cup Technique" and Solid State Nuclear Track Detectors, "SSNTD." The uranium concentration activity of the samples is found to vary from 0.62 to $4.68 \mathrm{ppm}$ with an average of $1.92 \pm 0.42 \mathrm{ppm}$. The radium concentration varies from 0.61 to $4.64 \mathrm{~Bq} \cdot \mathrm{kg}^{-1}$, with an average of $1.91 \pm 0.42 \mathrm{~Bq} \cdot \mathrm{kg}^{-1}$, the radon concentration in the samples varies from 42.29 to $319.97 \mathrm{~Bq} \cdot \mathrm{m}^{-3}$ with an average of $131.53 \pm 28.94 \mathrm{~Bq} \cdot \mathrm{m}^{-3}$. The value of the dissolved radon concentration in the collected samples varies from 12.99 to $98.97 \mathrm{~Bq} \cdot \mathrm{m}^{-3}$ with an average of $40.41 \pm 8.89 \mathrm{~Bq} \cdot \mathrm{m}^{-3}$. The mass exhalation rates are found to vary from 1.54 to $11.65 \mathrm{mBq} \cdot \mathrm{kg}^{-1} \cdot \mathrm{h}^{-1}$, with an average of $4.79 \pm 1.05 \mathrm{mBq} \cdot \mathrm{kg}^{-1} \cdot \mathrm{h}^{-1}$, while the surface inhalation rates vary from 76.97 to $582.35 \mathrm{mBq} \cdot \mathrm{m}^{-2} \cdot \mathrm{h}^{-1}$, with an average of $239.38 \pm 52.66 \mathrm{mBq} \cdot \mathrm{m}^{-2} \cdot \mathrm{h}^{-1}$. The AED due to indoor uses varies from 1.07 to $8.07 \mathrm{mSv} \cdot \mathrm{y}^{-1}$, with an average of $3.32 \pm 0.73 \mathrm{mSv} \cdot \mathrm{y}^{-1}$. The AED due to indoor plus outdoor uses varies from 1.47 to $11.10 \mathrm{mSv} \cdot \mathrm{y}^{-1}$, with an average of $4.56 \pm 1.0 \mathrm{mSv} \cdot \mathrm{y}^{-1}$. The results of this study show that the values obtained for most samples are within the internationally accepted recommended values. Therefore, these samples can be used as building materials as they do not pose a major risk to humans.

\section{Introduction}

Naturally occurring isotopes existing in the environment is a vital source of radiation exposure to humans that elevate background radiation level. Everybody has significant amounts of radiation that develops due to their exposure to naturally occurring radioactive materials. Radioactive nuclides are found in the air, clay, and sandy soils as well as in the food that we eat or by exhalation and deposition in the body's tissues [1]. The primary natural contributors to external exposure doses are $\mathrm{U}, \mathrm{Ra}$, and $\mathrm{Rn}$. Because these radioactive nuclides are not equally distributed, the knowledge of their presence in soils and rocks as trace amounts play an essential role in radiation exposure measurement. It is mandatory to check building materials as a potential source that contributes to total radiation dose [2]. The contribution of gamma rays emitted from ${ }^{226} \mathrm{Ra},{ }^{232} \mathrm{Th}$, and ${ }^{40} \mathrm{~K}$ to public exposure dose are about $55.5 \%$ for ${ }^{226} \mathrm{Ra}, 14 \%$ for ${ }^{232} \mathrm{Th}$, and $13.8 \%$ for ${ }^{40} \mathrm{~K}$ [3]. From the worldwide average doserate, about $8 \%$ dose is due to radiation exposure of terrestrial radionuclides, which is equivalent to $60.9 \mathrm{nGy} \cdot \mathrm{h}^{-1}$ (equivalent to an effective dose of $74.7 \mu \mathrm{Sv} \cdot \mathrm{y}^{-1}$ ), especially for areas with a common background [4]. Considerable contributors to indoor radon ${ }^{222} \mathrm{Rn}$ depend on building materials; ${ }^{222} \mathrm{Rn}$ is the daughter of ${ }^{226} \mathrm{Ra}$, which, in turn, is derived from a longer parent ${ }^{238} \mathrm{U}$. 
The external exposure dose to people is due to naturally occurring isotopes, which vary based on the surrounding geological nature and geographical altitude conditions in the region in which people live. Granite is the more favorable natural material that contains uranium. However, it usually is possible to find bedrocks rich in uranium or different types used in the domestic market as building materials. Building materials are sources of aerosol radioactivity. In addition, external radiation also occurs as a result of the decay series of uranium in buildings. However, radon inlet into houses is a complicated process involving building materials, soil, gas, water, and weather-related parameters, where ${ }^{226} \mathrm{Ra}$ in construction materials in some cases are the primary source. Much of the radon releases originate from radium trapped in mineral grains of building materials. In building materials that possess high radium activity, it is crucial that the radon exhalation rates be measured [5].

Some regions usually suffer from a higher level of exposure doses such as cities, whereas in mountains of Magma and fire rocks in China, India, Afghanistan, etc., the exposure rate may vary depending on the different seasons and variations in radon emanation rate [6]. A considerable amount of ${ }^{226} \mathrm{Ra}$ decay products are brought to the ground surface via many shallow and deep groundwaters, which rise up during earthquakes [7]. Recently, radon exhalation rate from building materials has become a significant topic in several works of literature $[1,5]$. Therefore, it is crucial to evaluate radioactivity in conventional building materials, where the existing radiation is due to alpha-emitters that are harmful, and cause energy to dissipate sharply in human body tissues. Therefore, $\mathrm{U}, \mathrm{Ra}$, and $\mathrm{Rn}$ concentrations, and radon exhalation rates for building materials must be investigated from a radiation safety point of view [2]. It is of utmost importance that we identify the amount of inhaled radon ${ }^{222} \mathrm{Rn}$ from these materials. This is because the short-lived products of radon decay will stay inside the lungs. This becomes the main contributors to lung dose [8]. Radon is a radioactive nuclide and is short-lived. It is the most hazardous isotope because of its gaseous nature, and potential for being exhaled by humans. In addition, all radioactive progenies of $\mathrm{U}, \mathrm{Ra}$, and $\mathrm{R}$ could adhere to aerosols. The trapping of such radioisotopes in the lungs leads to deposition of their alpha-particle energies in body tissues. Alpha-particles, in turn, produce a higher ionization density than beta particles or gamma rays. The exposure dose of the population to a high activity level of alpha-particle emitters, especially on most of the radon, over a long time, will lead to pathological, as well as functional effects in the respiratory system. Eventually, lung cancer could result. Lung cancer, kidney diseases, and skin cancer are due to the exhalation of radon decay products, causing various adverse health effects [8]. Hence, it is mandatory to study the concentration measurements of alpha emitters in building materials and the extent to which alpha emissions cause various diseases, especially lung cancer. The principal objective of this work is therefore to measure radon exhalation rate and annual effective doses due to radon activity across multiple building materials used for paving works and constructional material works in Saudi Arabia.

\section{Materials and Methods}

\section{Collection and preparation of samples}

Twenty-four building material samples were collected from customarily used building materials available on the market, randomly taken from housing locations, other buildings that are under construction, and from building material suppliers in Saudi Arabia in December 2016. The customarily used building materials include marble, granite, brick, block, concrete, gypsum, and mosaic, as shown in table (1). These samples were prepared such that their volume and surface were measured, crushed, milled, and sieved using a $2 \mathrm{~mm}$ mesh, and then dried in an oven. Then, about 75-100 g of each building material sample was placed indoors, then covered securely and placed in polyethylene cylindrical gas-tight vessels with a volume of $360 \mathrm{~cm}^{3}$ and cross-sectional area of $20 \mathrm{~cm}^{2}$, as shown in figure 1 . 


\begin{tabular}{|c|c|c|c|c|c|c|c|c|c|c|c|c|}
\hline \multirow{2}{*}{$\begin{array}{l}\text { Sample } \\
\text { no. }\end{array}$} & \multirow{2}{*}{$\begin{array}{l}\text { Building } \\
\text { material } \\
\text { samples }\end{array}$} & \multirow{2}{*}{$\begin{array}{c}\text { Building } \\
\text { material } \\
\text { Code }\end{array}$} & \multirow{2}{*}{$\begin{array}{c}\rho \times 10^{3} \\
\text { track } \cdot \mathrm{cm}^{-2}\end{array}$} & \multirow{2}{*}{$\underset{(p p m)}{C_{u}}$} & \multirow{2}{*}{$\underset{\mathrm{Bq}}{\mathrm{C}_{\mathrm{Ra}} \cdot \mathrm{kg}^{-1}}$} & \multirow{2}{*}{$\begin{array}{c}C_{R n} \\
B q \cdot m^{-3}\end{array}$} & \multirow{2}{*}{$\begin{array}{l}C_{s} \times 10^{3} \\
B q \cdot m^{-3}\end{array}$} & \multirow{2}{*}{$\begin{array}{c}E_{x}(M) \\
m B q \cdot k g^{-1} \cdot h^{-1}\end{array}$} & \multirow{2}{*}{$\begin{array}{c}E_{x}(S) \\
B q \cdot m^{-2} \cdot h^{-1}\end{array}$} & \multicolumn{2}{|c|}{$\begin{array}{c}\text { Annual effective dose } \\
\qquad m S v \cdot y^{-1}\end{array}$} & \multirow{2}{*}{$\begin{array}{c}\text { AED } \\
\operatorname{limit}<5 \\
m S v \cdot y^{-1}\end{array}$} \\
\hline & & & & & & & & & & Indoor & Outdoor & \\
\hline 1 & Granite & GT & 21.37 & 4.68 & 4.64 & 319.97 & 98.30 & 11.65 & 582.35 & 8.07 & 3.03 & $x$ \\
\hline 2 & Marble & $\mathrm{ML}$ & 15.68 & 3.43 & 3.40 & 234.84 & 72.15 & 8.55 & 427.42 & 5.92 & 2.22 & $x$ \\
\hline 3 & Gray Cement & $\mathrm{GC}$ & 13.49 & 2.95 & 2.93 & 201.98 & 62.05 & 7.35 & 367.61 & 5.10 & 1.91 & $x$ \\
\hline 4 & $\begin{array}{l}\text { Engineering } \\
\text { Bricks }\end{array}$ & EB & 13.19 & 2.89 & 2.86 & 197.55 & 60.69 & 7.19 & 359.55 & 4.98 & 1.87 & $x$ \\
\hline 5 & Ceramics & $\mathrm{CR}$ & 12.86 & 2.81 & 2.79 & 192.59 & 59.17 & 7.01 & 350.52 & 4.86 & 1.82 & $x$ \\
\hline 6 & Mosaic Tiles & MT & 12.86 & 2.81 & 2.79 & 192.59 & 59.17 & 7.01 & 350.52 & 4.86 & 1.82 & $x$ \\
\hline 7 & Concrete Bricks & $\mathrm{KB}$ & 12.55 & 2.75 & 2.72 & 187.88 & 57.72 & 6.84 & 341.93 & 4.74 & 1.78 & $x$ \\
\hline 8 & Soft gypsum & SG & 9.29 & 2.03 & 2.02 & 139.14 & 42.75 & 5.06 & 253.24 & 3.51 & 1.32 & $\sqrt{ }$ \\
\hline 9 & Porcelain & PC & 8.47 & 1.85 & 1.84 & 126.83 & 38.97 & 4.62 & 230.84 & 3.20 & 1.20 & $\checkmark$ \\
\hline 10 & Stone & ST & 7.84 & 1.72 & 1.70 & 117.44 & 36.08 & 4.27 & 213.74 & 2.96 & 1.11 & $\sqrt{ }$ \\
\hline 11 & Rock & RK & 7.70 & 1.69 & 1.67 & 115.35 & 35.44 & 4.20 & 209.93 & 2.91 & 1.09 & $\checkmark$ \\
\hline 12 & Limestone & LS & 7.53 & 1.65 & 1.63 & 112.73 & 34.63 & 4.10 & 205.16 & 2.84 & 1.07 & $\checkmark$ \\
\hline 13 & Cement Tiles & $\mathrm{CT}$ & 7.53 & 1.65 & 1.63 & 112.73 & 34.63 & 4.10 & 205.16 & 2.84 & 1.07 & $\checkmark$ \\
\hline 14 & White Cement & WC & 7.53 & 1.65 & 1.63 & 112.73 & 34.63 & 4.10 & 205.16 & 2.84 & 1.07 & $\sqrt{ }$ \\
\hline 15 & Heavy gravel & $H G$ & 7.21 & 1.58 & 1.57 & 108.01 & 33.18 & 3.93 & 196.58 & 2.72 & 1.02 & $\checkmark$ \\
\hline 16 & Muddy Bricks & MB & 7.21 & 1.58 & 1.57 & 108.01 & 33.18 & 3.93 & 196.58 & 2.72 & 1.02 & $\sqrt{ }$ \\
\hline 17 & $\begin{array}{c}\text { Burnt Clay } \\
\text { Bricks }\end{array}$ & BB & 6.78 & 1.48 & 1.47 & 101.52 & 31.19 & 3.70 & 184.77 & 2.56 & 0.96 & $\checkmark$ \\
\hline 18 & Thermiston & TS & 6.66 & 1.46 & 1.45 & 99.79 & 30.66 & 3.63 & 181.62 & 2.52 & 0.94 & $\sqrt{ }$ \\
\hline 19 & Light gravel & LG & 5.46 & 1.20 & 1.19 & 81.78 & 25.13 & 2.98 & 148.84 & 2.06 & 0.77 & $\sqrt{ }$ \\
\hline 20 & Cement Block & $\mathrm{CB}$ & 5.33 & 1.17 & 1.16 & 79.83 & 24.52 & 2.91 & 145.29 & 2.01 & 0.76 & $\sqrt{ }$ \\
\hline 21 & $\begin{array}{l}\text { Sand-Lime } \\
\text { Bricks }\end{array}$ & SB & 4.55 & 0.99 & 0.99 & 68.08 & 20.92 & 2.48 & 123.91 & 1.72 & 0.64 & $\sqrt{ }$ \\
\hline 22 & Fossil Sand & FS & 3.76 & 0.82 & 0.82 & 56.36 & 17.32 & 2.05 & 102.58 & 1.42 & 0.53 & $\sqrt{ }$ \\
\hline 23 & Washed Sand & WS & 3.11 & 0.68 & 0.68 & 46.63 & 14.33 & 1.70 & 84.87 & 1.18 & 0.44 & $\checkmark$ \\
\hline 24 & Gypsum & GM & 2.82 & 0.62 & 0.61 & 42.29 & 12.99 & 1.54 & 76.97 & 1.07 & 0.40 & $\sqrt{ }$ \\
\hline \multicolumn{3}{|c|}{ Maximum } & 21.37 & 4.68 & 4.64 & 319.97 & 98.30 & 11.65 & 582.35 & 8.07 & 3.03 & $x$ \\
\hline \multicolumn{3}{|c|}{ Minimum } & 2.82 & 0.62 & 0.61 & 42.29 & 12.99 & 1.54 & 76.97 & 1.07 & 0.40 & $\sqrt{ }$ \\
\hline \multicolumn{3}{|c|}{ Average } & 8.78 & 1.92 & 1.91 & 131.53 & 40.41 & 4.79 & 239.38 & 3.32 & 1.24 & $\checkmark$ \\
\hline \multicolumn{3}{|c|}{ Standard Deviation } & 1.93 & 0.42 & 0.42 & 28.94 & 8.89 & 1.05 & 52.66 & 0.73 & 0.27 & -- \\
\hline
\end{tabular}

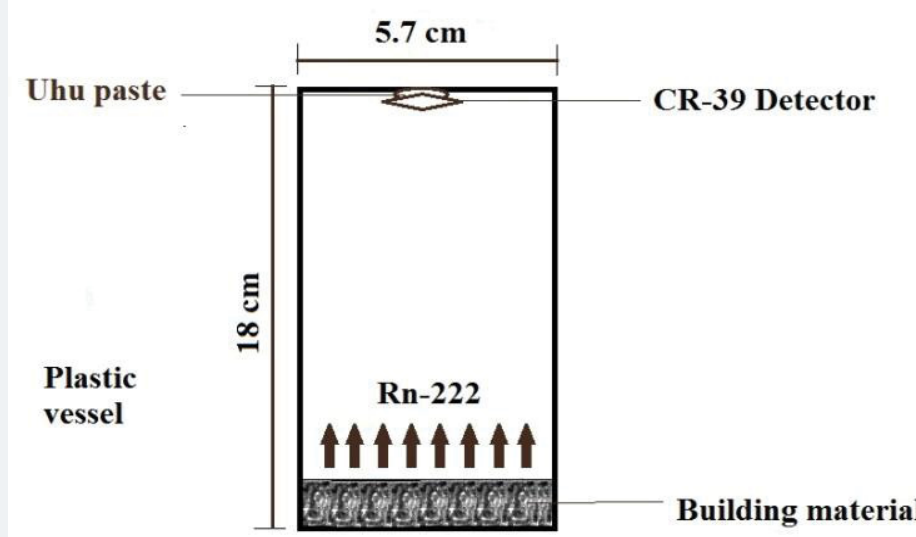

Figure 1: Sketch of the sealed-cup technique with a sample of the building material.

The SSNTD, which is generally a polyallyl diglycol carbonate $\left(\mathrm{C}_{12} \mathrm{H}_{18} \mathrm{O}_{7}\right)$ commercially known as $C R-39$ track detector, faces the sample, as per figure 1 . The dosimeters were sealed entirely for a period of four weeks to obtain equilibrium between ${ }^{226} R a$ and ${ }^{222} R n$. This procedure is essential to guarantee that the radon gas and its progenies are at equilibrium and are confined within the sealed cup. ACR39 detector was placed at the closed upper end of the plastic cup $(5.7 \mathrm{~cm}$ diameter and $18 \mathrm{~cm}$ length). Meanwhile, the sample-detector distance was kept at $16 \mathrm{~cm}$, and a fixed volume $\left(40 \mathrm{~cm}^{3}\right)$ of building material samples was maintained in the plastic cups, as shown in figure 1. 
The ratio of the volume of the cups to the sample was more than 10 , which reduces the probability of back diffusion [9], while the distance between the sample surface and the detector was about $16 \mathrm{~cm}$, which reduces the thoron. The $\left({ }^{220} \mathrm{Rn}\right)$ concentration around the detector approaches at most $10 \%$ of the total thoron concentration close to the sample surface, but the effects of thoron contribution on the detector readings are insignificant [10]. The cups were hermetically sealed and stored for about 100 days. We then determined the uranium concentration, effective radium concentration, radon exhalation rate, and the annual effective doses in building material samples using the passive technique called Solid State Nuclear Track Detectors, and the "sealed-cup technique" [11].

\section{Etching and scanning process}

The radon gas produces tracks of alpha particles emitted after the alpha decay of radium concentration in the samples. The exposure of the detectors to alpha-emitter gas in the vessel continues for about 100 days. After exposure, we retrieve the detectors and etch them for six hours in $6.25 \mathrm{~N} \mathrm{NaOH}$ solution maintained in an etching bath with a magnetic stirrer at a constant temperature of $(70 \pm 1)^{\circ} C$ to enlarge the tracks. The detectors are then washed and dried. Subsequently, we count the alpha tracks using an optical microscope (Krüss MBL2000) at a magnification of 400x (40x objective and 10x eyepiece). The alpha-particle emitted concentrations from radon gas that emerge from the building material samples are determined using a nuclear track detector $C R$ 39 of $250 \mu \mathrm{m}$ thickness and an area of about $\left(1 \times 1 \mathrm{~cm}^{2}\right)$. To determine the background distribution due to radionuclides that occur naturally in the environment around the detector, we prepare an empty vessel with a detector in the same place as the samples. This value is later subtracted from every reading once the background activity concentration is determined.

\section{Calculation process}

Radon concentration: The alpha particles are emitted by radon bombarding a CR39 detector, which makes tracks inside it. These tracks are scanned using an optical microscope. The area of the field of view is equal to $\left(5.3 \times 10^{-3} \mathrm{~cm}^{-2}\right)$, while the track density is defined as the integral number of tracks per field of view and counted per $\mathrm{cm}^{-2}$. The calculated tracking density was converted to radon activity in $B q \cdot \mathrm{m}^{-3}$ using a calibration factor $(\mathrm{k})$, which is obtained from the date sheet of the manufacturer $\left(B q \cdot \mathrm{m}^{-3}\right) \cdot\left(\text { tracks } \cdot \mathrm{cm}^{-2} \cdot \mathrm{day}^{-1}\right)^{-1}$, where every track recorded per one $\mathrm{cm}^{-2}$ per day on the $C R-39$ detector is equivalent to $23.1 \mathrm{Bqm}^{-3}$. This is due to exposure to a variety of activities derived from radon gas and its progenies.

The track density $\rho$ is measured using Equation (1): [12].

$$
\rho=\frac{\sum_{i} N_{i}}{n \cdot A}
$$

Where, $\rho$ is track density (in tracks $\cdot \mathrm{cm}^{-2}$ ) and corresponds to the concentration $C_{R n}$ of radon activity (in $\mathrm{Bqm}^{-3}$ ), $N_{i}$ is the total number of tracks, $n$ is the total number of fields of views, and $A$ is the area of the field of view.

The exposure time $t$ is derived using Equation (2): [13].

$$
\rho=C_{R n} \cdot \eta \cdot t,
$$

Where, $\eta$ is the detector sensitivity factor of $C R-39$ plastic track detector, equal to $4.3319 \times 10^{-2}$ tracks $\cdot \mathrm{cm}^{-2} \cdot d a y^{-1} \cdot\left(B q \cdot \mathrm{m}^{-3}\right)^{-1}, k$ is the calibration factor $(\mathrm{k}=1 / \eta)$, assuming that the half-life of ${ }^{226} \mathrm{Ra}$ and ${ }^{222} \mathrm{Rn}$ is 1625 years and 3.82 days, respectively. It is rational to assume that a secular equilibrium (approximately 99\%) of the radonradon members of the decay series is achieved within four weeks, almost. As soon 
as the radioactive equilibrium has been reached, the analysis of alphas emitted from radon could be used to estimate the steady-state activity concentration of radon. Once the radioactive equilibrium has been verified, the alpha-radon assay can be used to determine the steady-state activity concentration of radon. The activity concentration of radon $C_{R n}$ begins to increase with time $t$, after the closing of the cup, according to the relationship portrayed in Equation (3): [1].

$$
C_{R n}\left(B q \cdot m^{-3}\right)=C_{R a}\left(1-e^{-\lambda_{R n} \cdot t}\right),
$$

where $C_{R a}$ (in $B q \cdot \mathrm{kg}^{-1}$ ) is the radium activity density of the sample and $\lambda_{R n}$ is the decay constant of ${ }^{222} R n\left(7.56 \times 10^{-3} h^{-1}\right)$. Then, the tracks in the detector are used to measure the time-integrated value of the density of the track, as per Equation (2), i.e., the integrated number of emitted alphas per unit volume due to disintegration, corresponding to the detector sensitivity $\eta$ through the exposure time $t$. Hence, the track density observed is given by Equation (4): [1].

$$
\rho=\eta \cdot C_{R n} \cdot t_{e f f},
$$

where $t_{\text {eff }}$ is the effective exposure time given by Equation (5): [14].

$$
t_{\text {eff }}=\left[t+\tau_{R n} \cdot\left(e^{-\lambda_{R n} \cdot t}-1\right)\right] \text {, }
$$

Where, $\tau_{R n}$ is the mean lifetime of radon. In this case, we found that Equation (6) provides more accurate results for obtaining effective exposure time:

$$
\begin{aligned}
& t_{\text {eff }}=\left[\left(t-7 \cdot t_{1 / 2}\right)+\tau_{R n} \cdot\left(e^{-\lambda_{R n} \cdot\left(t-7 \cdot t_{1 / 2}\right)}-1\right)\right], \\
& t_{e f f}=\left[\left(\exp \left(-\lambda_{R n} \cdot\left(t-7 \cdot t_{1 / 2}\right)\right)+\left(\lambda_{R n} \cdot\left(t-7 \cdot t_{1 / 2}\right)\right)-1\right)\right] / \lambda_{R n} .
\end{aligned}
$$

The concentration of dissolved radon gas in building material sample $C_{s}$ is calculated using Equation (7): [15].

$$
C_{S}\left(B q \cdot m^{-3}\right)=\frac{h \cdot t}{L} \cdot \lambda_{R n} \cdot C_{R n},
$$

where, $h$ is the gap distance, separating the upper surface of the building material sample and the detector, measured in meter $(0.16 \mathrm{~m}), t$ is time of exposure (100 days), $L$ is the depth of the sample $(0.02 \mathrm{~m}), \lambda_{R n}$ is the decay constant for radon, and $C_{R n}$ is the radon activity density in ambient air $\left(B q \cdot \mathrm{m}^{3}\right)$.

\section{Effective radium concentration}

To calculate the effective radium concentration of the building material sample, we apply Equation (8): [16].

$$
C_{R a}\left(B q \cdot k g^{-1}\right)=\left(\frac{\rho}{\eta \cdot t_{e f f}}\right) \cdot\left(\frac{V}{M}\right)
$$

where $A$ is the area of the cup cross-sectional per $\left(\mathrm{m}^{2}\right), M$ is the sample mass of the building materials per $(\mathrm{kg}), t_{\text {eff }}$ is the effective exposure time, and $V$ is the void volume of the container $\left(\mathrm{m}^{3}\right)$, where $V=h \cdot A$.

\section{Radon exhalation rates}

The mass exhalation rate $E_{x}(M)$ of the sample for the release of radon is calculated using Equation (9): [14].

$$
E_{x}(M)\left(B q \cdot \mathrm{kg}^{-1} \cdot \mathrm{d}^{-1}\right)=\left(\frac{C_{R a}}{t_{\text {eff }}}\right) \cdot\left(\frac{\lambda_{R a}}{\lambda_{R n}}\right) \text {. }
$$

The surface exhalation rate $E_{x}(S)$ of the sample for the release of radon is calculated using Equation (10): [17]. 


$$
\begin{aligned}
& E_{x}(S)\left(m B q \cdot m^{-2} \cdot h^{-1}\right)=\left(\frac{C_{R a}}{t_{e f f}}\right) \cdot\left(\frac{\lambda_{R a}}{\lambda_{R n}}\right) \cdot\left(\frac{M}{A}\right), \\
& E_{x}(S)\left(m B q \cdot m^{-2} \cdot h^{-1}\right)=E_{x}(M) \cdot\left(\frac{M}{A}\right),
\end{aligned}
$$

where $\lambda_{R a}$ is the decay constant of ${ }^{226} R a$.

\section{Uranium concentration}

To determine the uranium concentration $C_{U}$ in parts-per-million (ppm) of the building material samples, Equation (12) is used [17].

$$
C_{U}(p p m)=\left(\frac{W_{U}}{W_{S}}\right) \text {, }
$$

where $W_{S}$ is the weight of the sample, and $W_{U}$ is the uranium weight in the sample, calculated from the following relationship:

$$
W_{u}=\frac{N_{u} \cdot M_{u}}{N_{a v}}
$$

where $M_{u}$ is the uranium molecular weight, $N_{u}$ is the number of uranium atoms, and $N_{a v}$ is Avogadro's number $\left(6.023 \times 10^{23}\right.$ atom $\left.\cdot \mathrm{mol}^{-1} \cdot \mathrm{g}^{-1}\right)$. When secular equilibrium is established, the following balance could be verified:

$$
N_{U} \cdot \lambda_{U}=N_{R a} \cdot \lambda_{R a},
$$

where $\lambda_{u}$ is the uranium decay constant $\left(4.98 \times 10^{-18} \mathrm{sec}^{-1}\right)$.

\section{Annual effective dose}

The estimated annual effective dose due to radon concentrations is compared with the recommendation of United Nations Scientific Committee on the Effects of Atomic Radiation "UNSCEAR," in its year 2000 report [18]. It is noted that the relationship between radon activity and recommended radon effective dose has a conversion factor of $9 \mathrm{nSv}$ per $\left(\mathrm{Bq} \cdot \mathrm{h} \cdot \mathrm{m}^{-3}\right)$. Assuming 7008 hours per year indoor (an indoor occupancyfactor of $80 \%$ of 8760 hours of a year, $20 \%$ for outdoors) and an equilibriumfactor of 0.4 for indoors, and 0.6 for outdoors [19], using the mentioned UNSCEAR recommendation, the effective dose for one-year radon exposure can be calculated using Equation (13): [18].

$$
\operatorname{Dose}\left(m S v \times y^{-1}\right)=C_{R n} \cdot T \cdot f_{R n} \cdot F_{e q},
$$

Where, $f_{R n}$ is the conversion factor $=9 \mathrm{nSv} \cdot\left(\mathrm{Bq} \cdot \mathrm{h} \cdot \mathrm{m}^{-3}\right)^{-1}$.

$T$ is the time spent indoors per year $=7008$ hours; outdoors per year $=1752$

$F_{e q}$ is the equilibrium fraction (0.4) for indoors, and (0.6) for outdoors,

$C_{R n}$ is the radon concentration.

Substituting the previous quantities in Equation (12), we get the annual effective dose according to the following relationship in Equations $(14,15)$ :

For indoors, the annual effective dose is given by Equation (14):

$$
\operatorname{Dose}\left(m S v \times y^{-1}\right)=0.02523 \cdot C_{R n} \text {. }
$$

For outdoors, the annual effective dose is given by Equation (15):

$$
\operatorname{Dose}\left(m S v \times y^{-1}\right)=0.00946 \cdot C_{R n} \text {. }
$$




\section{Results and Discussion}

In this work, twenty-four samples of various building materials were analyzed by utilizing the sealed-cup technique. Table 1 shows the measured uranium, radium, radon, dissolved radon concentrations, mass and surface exhalation rates, and annual effective dose for the building material samples per $(\mathrm{kg})$. From this data, we can determine the uranium concentration, as per table 1, for various building material samples from local markets in Saudi Arabia. It appears that the highest level of uranium concentration was $4.68 \mathrm{ppm}$, owing to GT (granite), whereas the lowest concentration of uranium was $0.62 \mathrm{ppm}$ in GM (Gypsum) with a mean value of $1.92 \pm 0.42 \mathrm{ppm}$. The value of effective radium concentration in the collected samples varies from 0.61 to $4.64 \mathrm{~Bq} \cdot \mathrm{kg}^{1}$ with an average value of $1.91 \pm 0.42 \mathrm{~Bq} \cdot \mathrm{kg}^{-1}$, the value of radon concentration in the collected samples varies from 42.29 to $319.97 \mathrm{~Bq} \cdot \mathrm{m}^{-3}$ with an average value of $131.53 \pm 28.94$ $B q \cdot \mathrm{m}^{-3}$. Also, the value of the dissolved radon concentration in the collected samples varies from 12.99 to $98.30 \mathrm{~Bq} \cdot \mathrm{m}^{-3}$ with an average value of $40.41 \pm 8.89 \mathrm{~Bq} \cdot \mathrm{m}^{-3}$. The mass exhalation rates have been found to vary from 1.54 to $11.65 \mathrm{mBq} \cdot \mathrm{kg}^{-1} \cdot \mathrm{h}^{-1}$. With an average value of $4.79 \pm 1.05 \mathrm{mBq} \cdot \mathrm{kg}^{-1} \cdot \mathrm{h}^{-1}$, while the surface exhalation rates vary from 76.97 to $582.35 \mathrm{mBq} \cdot \mathrm{m}^{-2} \cdot \mathrm{h}^{-1}$, with an average value of $239.38 \pm 52.66 \mathrm{mBq} \cdot \mathrm{m}^{-2} \cdot \mathrm{h}^{-1}$. The total annual effective dose due to indoor and outdoor uses varies from 1.47 to 11.10 $m S v \cdot y^{-1}$, with an average value of $4.56 \pm 1.0 \mathrm{mSv} \cdot \mathrm{y}^{-1}$. The uranium concentration from the obtained results in most samples was lesser than the global average concentration of uranium in the soil, which is 3 ppm except for the granite and marble samples [18].

Figure 2 shows the distribution of uranium and radium concentrations in various building material samples of Saudi Arabia, while figure 3 shows the radon gas concentration in the void and dissolved radon concentration in the solid from different building material samples. Figure 4 shows the distribution of mass and surface exhalation rates for radon from several building material samples. Figure 5 shows the indoor and outdoor annual effective doses due to different building material samples. By reviewing the mass and surface exhalation rates, the obtained values for radon can be determined, and are shown in table 1 . The value of this data is lesser than that mentioned in several works of literature [17,19-22]. Radon exhalation rates observed in the current study are also quite below the world average of $57,600 \mathrm{mBq} \cdot \mathrm{m}^{-2} \cdot \mathrm{h}^{-1}$ $\left(0.016 \mathrm{~Bq} \cdot \mathrm{m}^{2} \cdot \mathrm{s}^{-1}\right)$ and hence will not cause any health hazards to residents [20].

Though this study, the uranium concentration data from the building material samples, as observed from table 1 , is found to be very small and insignificant in causing health hazards. The radium concentrations, as shown in table 1 , are lesser in value than the reported results given in several works of literature [23-25]. The effective radium concentration data is lower than the permissible limit of $370 \mathrm{~Bq} \cdot \mathrm{kg}^{-1}$, as per the recommendation from the Organization for Economic Cooperation and Development

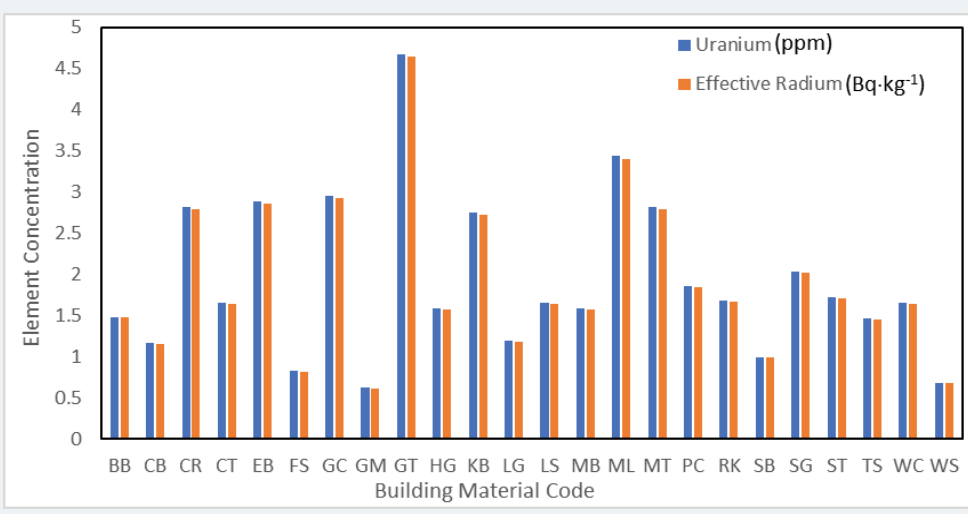

Figure 2: Uranium and effective radium concentrations from different building material samples. 

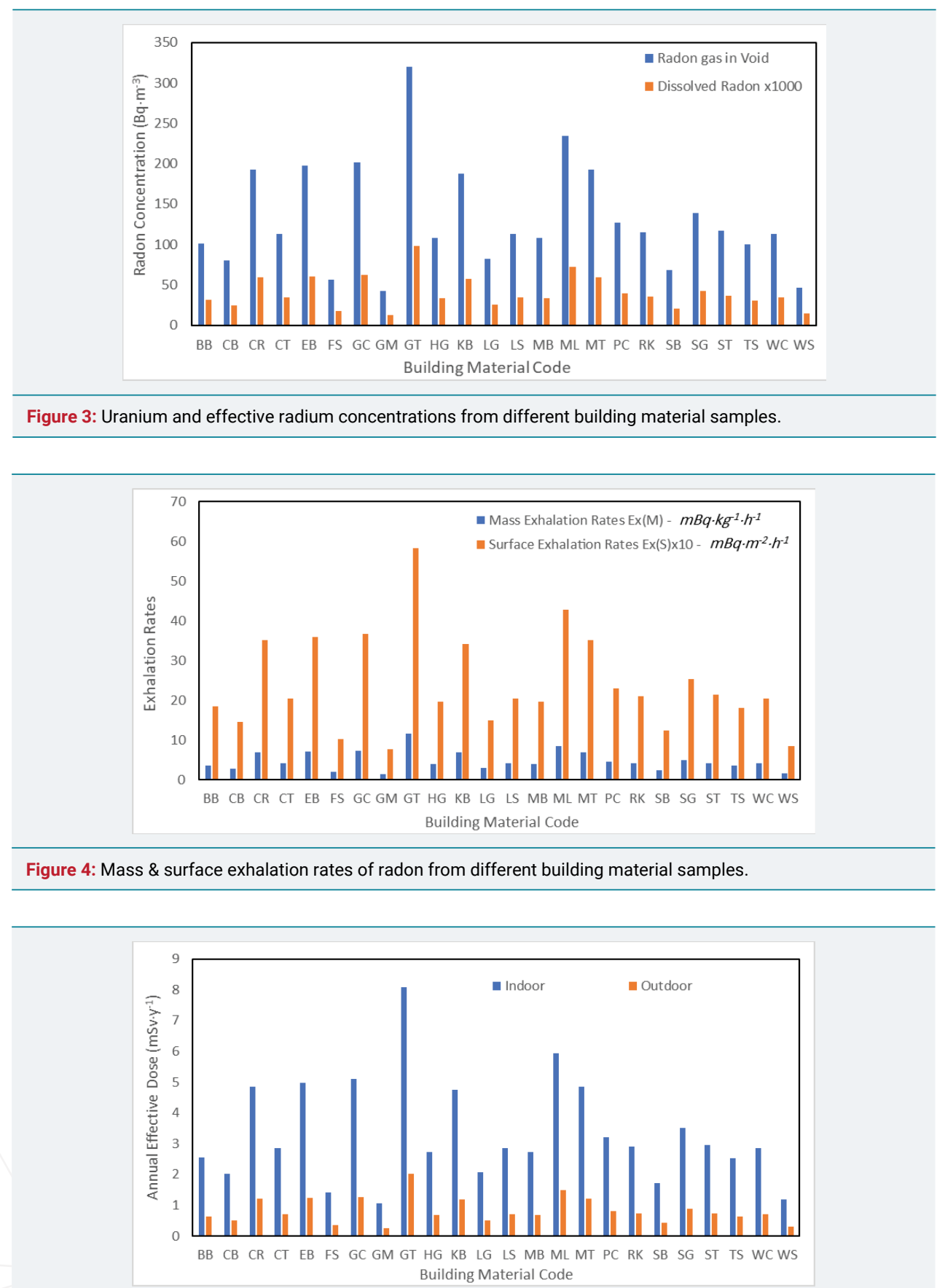

Figure 5: Indoor \& outdoor annual effective doses due to different building material samples.

"OECD" [26]. Hence, the results show that these building materials are safe and are not a radium health hazard. This means that the building materials taken from the locations or suppliers will not induce any dangerous levels of indoor radon.

Consequently, the annual effective doses from granite, marble, gray cement, engineering bricks, ceramics, mosaic tiles, and concrete brick samples are higher than the recommended values set by the National Council on Radiation Protection and Measurements "NCRP" report NCRP-168 [27], the International Commission on Radiological Protection "ICRP" report ICRP-118 [28], and the UNSCEAR-2000 report [18]. The maximum value for public exposure is set at $1 \mathrm{mSv} \cdot y^{-1}$. For occupational workers, the exposure is $20 \mathrm{mSv} \cdot y^{1}$. The typical range of radiation dose from natural sources is from 1 to $10 \mathrm{mSv} \cdot y^{-1}$ with an average of $5 \mathrm{mSv} \cdot y^{-1}$. This is because the annual worldwide per individual effective dose is determined via the addition of various components of external exposure from cosmic rays and terrestrial gamma rays as well 
as internal exposure from inhalation (mainly radon) and ingestion. Obviously, we can observe that some samples are not safe to be used as building materials if used on a broad spectrum in Saudi Arabia. It is therefore essential to legalize the amount used in buildings and houses. Meanwhile, we must also note that the radon concentrations measured using the sealed-cup technique indicate that the air during the whole exposure time was confined within the cup; thus, providing excellent ventilation conditions in buildings will eliminate significant exposure to this hazard and result in a lower dose. These high doses are apparently due to the high concentration of radium samples and low level in the other samples, as per table 1.

\section{Conclusions}

The sealed-cup technique uses SSNTD. It is an efficient, cheap, and useful tool for measuring long-term radon exhalation rate, radium concentration, and uranium concentration. Values obtained for annual effective doses of granite, marble and gray cement samples are more than $5 \mathrm{mSv} \cdot y^{-1}$, for which engineering bricks, ceramics, mosaic tiles, and concrete brick samples approach this value. Therefore, the radon exhalation rate from buildings constructed from these materials is high, and a warning restriction of their use in building construction must be issued. In addition, the elevated radon concentrations measured via the sealed-cup technique means that the air during the whole exposure time was confined within the cup. Thus, by ensuring proper ventilation conditions in buildings, reducing the amounts of these materials will eliminate significant exposure and result in a lower dose.

The radon exhalation in these samples was found to be well below the average world value of $57,600 \mathrm{mBq} \cdot \mathrm{m}^{-2} \cdot \mathrm{h}^{-1}\left(0.016 \mathrm{~Bq} \cdot \mathrm{m}^{-2} \cdot \mathrm{s}^{-1}\right)$. Hence, it is concluded that these materials may be used for construction purposes, as they do not pose any health hazards. It is mandatory to study the radon exhalation rates, so as to understand the contribution of the building material towards total radon concentrations in dwellings, in addition to its involvement in water supplies, especially in groundwater resources. Hence, we conclude that the obtained doses from the sample building materials in Saudi Arabia are quite safe and do not pose any radiation health hazards.

\section{References}

1. Rastogi N, Singh I. Levels of natural radioactivity in environment in residential area of Moradabad District, Western Uttar Pradesh. Pollution. 2017; 3; 1-7. Ref.: https://goo.gl/RWjHKT

2. Khan AR, Rafique M, Rahman SU, Kearfott KJ, Matiullah. A review of radon measurement studies with nuclear track detectors (NTDs) in Azad Kashmir. Indoor and Built Environment. 2017; 26: 447455. Ref.: https://goo.gl/FQjhYT

3. Bavarnegin E, Vahabi-moghaddam M, Babakhani A, Fathabadi N. Analytical study of radionuclide concentration and radon exhalation rate in market available building materials of Ramsar. Journal of Theoretical and Applied Physics. 2012; 6: 5. Ref.: https://goo.gl/wWLgwe

4. Hosoda M, Tokonami S, Omori Y, Ishikawa T, Iwaoka K. A comparison of the dose from natural radionuclides and artificial radionuclides after the Fukushima nuclear accident. J Radiat Res. 2016; 57: 422-430. Ref.: https://goo.gl/4f2y3M

5. Bossew $P$. The radon emanation power of building materials, soils, and rocks. Applied Radiation and Isotopes. 2003; 59: 389-392. Ref.: https://goo.gl/3MwsHx

6. Shahbazi-Gahrouei D. Natural background radiation Dosimetry in the highest altitude region of Iran. J Radiat Res. 2003; 44: 285-287. Ref.: https://goo.gl/q7qx6k

7. Deb A, Gazi M, Barman C. Anomalous soil radon fluctuations-a signal of earthquakes in Nepal and eastern India regions. Journal of Earth System Science. 2016; 125: 1657-1665. Ref.: https://goo.gl/KnjNck

8. Damla N, Kara A, Tel E, Yesilkanat CM. Mapping of indoor radon survey and dose estimations in health centers in Turkey. Indoor and Built Environment. 2017; 26: 327-336. Ref.: https://goo.gl/Cz6LNS

9. Hafez AF, Hussein AS, Rasheed NM. A study of radon and thoron release from Egyptian building materials using polymeric nuclear track detectors. Applied Radiation and Isotopes. 2001; 54: 291 298. Ref.: https://goo.gl/ADYqgA 
10. Somogyi G, Hafez AF, Hunyadi I, Tóth-Szilágyi M. Measurement of exhalation and diffusion parameters of radon in solids by plastic track detectors. International Journal of Radiation Applications and Instrumentation. Part D. Nuclear Tracks and Radiation Measurements. 1986; 12 : 701-704. Ref.: https://goo.gl/2q9C4b

11. Abo-Elmagd M, Daif MM. Calibration of CR-39 for radon-related parameters using sealed cup technique. Radiat Prot Dosimetry. 2010; 139: 546-550. Ref.: https://goo.gl/9AjtdA

12. Kropat G, Baechler S, Bailat C, Barazza F, Bochud F, et al. Calibration of the Polytrack system based on CR39 solid-state nuclear track detectors for passive indoor radon concentration measurements. Radiat Prot Dosimetry. 2015; 167: 302-305. Ref.: https://goo.gl/uUZvLb

13. Misdaq MA, Elouardi B, Ouguidi J. Rn-222, Rn-220 and their progenies measured in the air of different dwellings and workplaces and resulting alpha radiation doses to the eyes of individuals. Health Physics. 2017; 113: 363-374.

14. Sroor A, El-Bahi SM, Ahmed F, Abdel-Haleem AS. Natural radioactivity and radon exhalation rate of soil in southern Egypt. Appl Radi Is. 2001; 55: 873-879. Ref.: https://goo.gl/2SHiLM

15. Kumar A, Chauhan RP, Joshi M, Sahoo BK. Modeling of indoor radon concentration from radon exhalation rates of building materials and validation through measurements. $J$ Environ Radioact. 2014; 50-55. Ref.: https://goo.gl/EnVZTP

16. Baykara 0 , Karatepe Ş, Doğru M. Assessments of natural radioactivity and radiological hazards in construction materials used in Elazig, Turkey. Radiation Measurements. 2011; 46: 153-158. Ref.: https://goo.gl/ictdKg

17. Moharram BM, Suliman MN, Zahran NF, Shennawy SE, El Sayed AR. 238U, 232Th content and radon exhalation rate in some Egyptian building materials. Annals of Nuclear Energy. 2012; 138-143. Ref.: https://goo.gl/HWpRVp

18. UNSCEAR. Effects of Ionizing Radiation. United, Nations, Scientific, Committee, on the Effects, of Atomic Radiation. 2000; 453-487.

19. Oikawa S, Kanno N, Sanada T, Abukawa J, Higuchi H. A survey of indoor workplace radon concentration in Japan. J Environ Radioact. 2006; 87: 239-245. Ref.: https://goo.gl/c3Mkyk

20. Singh $H$, Singh $J$, Singh $S$, Bajwa BS. Radon exhalation rate and uranium estimation study of some soil and rock samples from Tusham ring complex, India using SSNTD technique. Radiation Measurements. 2008; 459-462. Ref.: Ref.: https://goo.gl/jWW1FHb

21. Mahmood A, Tufail M. Measurement of radon concentration for assessment of the radiologica hazard in the Chakwal coalmines of the Salt Range, Pakistan. Journal of Radiological Protection. 2011; 31: 353-367. Ref.: https://goo.gl/JdQeZ1

22. Yousef HA, Saleh GM, El-Farrash AH, Hamza A. Radon exhalation rate for phosphate rocks samples using alpha track detectors. Journal of Radiation Research and Applied Sciences. 2016; 9: 41-46. Ref.: https://goo.gl/eBm2Sm

23. Baykara O, Doğru M, Inceöz M, Aksoy E. Measurements of radon emanation from soil samples in triple-junction of North and East Anatolian active faults systems in Turkey. Radiation Measurements. 2005; 39: 209-212. Ref.: https://goo.gl/9UEmnB

24. Baykara O, Dog `ru M. Measurements of radon and uranium concentration in water and soil samples from East Anatolian Active Fault Systems (Turkey). Radiation Measurements. 2006; 41: 362-367. Ref.: https://goo.gl/qp1URb

25. Nasir T, Shah M. Measurement of annual effective doses of radon from drinking water and dwellings by CR-39 track detectors in Kulachi City of Pakistan. Journal of Basic \& Applied Sciences. 2012; 8: 528-536. Ref.: https://goo.gl/p8J6cjc

26. OECD. Exposure to radiation from the natural activity in building materials. Organisation for Economic Co-operation Development. Nuclear Energy Agency. 1979.

27. NCRP. Guidance for emergency response dosimetry. National Council on Radiation Protection Measurements. 2017.

28. Stewart FA, Akleyev AV, Hauer-Jensen M, Hendry JH, Kleiman NJ, et al. ICRP publication 118: ICRP statement on tissue reactions and early and late effects of radiation in normal tissues and organs-threshold doses for tissue reactions in a radiation protection context. Ann ICRP. 2012; 41: 1-322. Ref.: https://goo.gl/XL5rNS 